\title{
Reading Philippe Desportes in Le Rencontre des muses de France et d'Italie
}

\author{
Gabriella Scarlatta Eschrich
}

The Renaissance poet Philippe Desportes (1546-1606) was considerably appreciated and admired during his lifetime. ${ }^{1}$ In 1573 , while the poet was leaving France for Poland in order to follow the Duke of Anjou (1551-89), who was the newly crowned King of Poland and future Henri III of France, his Premières Euvres was published in Paris. ${ }^{2}$ From that year on, a new edition of his poems would be published almost every year until 1602, with a total of thirty-three editions in thirty years. His poetry, esteemed for its lyric and clear qualities, met with great success and fulfilled the expectations of his readers, patrons and fellow writers. Desportes succeeded Pierre de Ronsard as the court poet of Henri III and he became the secretary of the king's chancellery. He was a favourite member of the salon of the Maréchale de Retz and an active participant in the Palace Academy of Henri III. These two institutions performed cultural, intellectual and social roles of great importance at the end of the sixteenth century, and they shaped and contributed to Desportes' writing and success. ${ }^{3}$ As the favourite poet of Henri III, he wrote to order and tried to respond to the demands and tastes of his public. Just before his death, Desportes became the tutor of Henri IV's son, the future Louis XIII. His

\footnotetext{
${ }^{1}$ Two important studies dedicated to Desportes and his writings have recently been published: Bruno Petey-Girard and François Rouget (eds.), Philippe Desportes. Poète profane, poète sacré. Actes du Colloque international de Chartres (14-16 septembre 2006) (Paris: Champion, 2008), and Jean Balsamo (ed.), Philippe Desportes (1546-1606). Un poète presque parfait entre Renaissance et Classicisme (Paris: Klincksieck, 2000). For an extensive biography, see Jacques Lavaud, Un Poète de cour au temps des derniers Valois. Philippe Desportes (Paris: Droz, 1936). My deep gratitude goes to my two colleagues Stéphane Spoiden and Jackie Vansant, as well as to the anonymous, patient reader for their indispensable comments and help in the various stages of this article.

${ }^{2}$ Les Premières Cuvres de Philippe Desportes au Roy de Pologne (Paris: Robert Estienne pour lui-même et Robert le Mangnier, 1573). The first modern edition of Desportes' poetry is by Alfred Michiels, Euvres de Philippe Desportes (Paris: Adolfe Delahais, 1858). A more recent edition of his work is by Victor Graham, Desportes, Philippe, Premières Euvres (Paris et Genève: Minard et Droz, 1958) in seven volumes. All references will be based on this edition.

${ }^{3}$ For Desportes' role in Henri III's Palace Academy, see 'Desportes orateur à l'Académie du Palais', in Philippe Desportes. Poète Profane, poètesacré, 23-100; Daniela Costa, 'Desportes et l'Académie du Palais', in Philippe Desportes (1546-1606), 163-72, and for his role in the Salon of the Maréchale de Retz, see Rosanna Gorris, 'Je veux chanter d'amour la tempeste et l'orage': Desportes et les Imitations de l'Arioste', in Philippe Desportes (1546-1606), 173-211; Frances A. Yates, The French Academies of the Sixteenth Century (London: Warburg Institute, 1947); Robert J. Sealy, The Palace Academy of Henri III, (Bibliothèque d'Humanisme et Renaissance, XI, 1971), 61-83; Mark Greengrass, Governing Passions. Peace and Reform in the French Kingdom, 1576-1585 (Oxford: Oxford University Press, 2007), 46-59.
} 
career flourished during the reign of three different kings, Charles IX, Henri III, and Henri IV, in three courts and under two dynasties, the Valois and Bourbons.

Desportes wrote extensively and in a variety of genres and styles. ${ }^{4}$ His poetry has almost always been analysed in relation to its sources, mostly the Italian Petrarchist and neo-Petrarchist poets of the Quattrocento and Cinquecento, or in relation to some of his contemporaries. ${ }^{5}$ This trend started while the poet was still alive when, in 1604, an anonymous editor published the pamphlet, Le Rencontre des Muses de France et d'Italie. The text was later attributed to R. J. de Saint-Jorry, ${ }^{6}$ who was undoubtedly familiar with Desportes' poetry and with the many Italian anthologies circulating in France during the end of the sixteenth century. This little-known volume, dedicated to the queen of France, Marie de Medici, brought together forty-three poems by Desportes and, on the facing page, forty-three Italian poems deemed to be his sources. The Rencontre is the embodiment of a perfect example of the literary and critical preoccupations of the Renaissance, and it raises several important questions dealing with the tension between mimesis and creativity, individuality and intertextuality, and, of course, language and Italianisms. Most importantly, I will argue here that the Rencontre contributes to a better understanding of Desportes and of how he read, adopted, and adapted his sources.

This study will focus on Le Rencontre des muses de France et d'Italie, a text that is rarely discussed yet is crucially important in the reading and interpretation of Desportes. It scrutinizes Saint- Jorry's intentions and position toward not only his 'rencontre' of two poetics, but also toward matters of imitation. While this preface has been mostly ignored by literary critics, it constitutes an important document because it eloquently sheds light on significant conventions of Renaissance imitation. Moreover, through a close reading and textual analysis of four paired sonnets from the Rencontre, I hope to identify some

\footnotetext{
${ }^{4}$ His Premières CEuvres (1573) includes: Le premier livre des Amours, Le second livre des Amours, Diverses Amours et autres cuvres meslées, les Amours d'Hippolyte; Elégies, a Latin play Ad Philipum Portaeum, and Imitations. For subsequent editions see Philippe Desportes (1546-1606), 513-34.

${ }^{5}$ See Jean Balsamo, who notes: 'En fait l'on n'a cessé d'opposer Desportes à Ronsard, Desportes à Malherbe dans ces duels si caractéristiques de l'historiographie française.' in Philippe Desportes (1546-1606), 8. A recent article on Desportes' imitation by Roberta Cavallini is also very compelling, 'L'Amour entre le profane et le sacré: échos pétrarquistes et nouvelles perspectives dans la poésie de Desportes', in Philippe Desportes. Poète profane, poète sacré, 167-80.

${ }^{6}$ Le Rencontre des muses de France et d'Italie, (Lyon, Jacques Roussin, 1604). The volume also includes the Dialogue de Minerve et Junon sur les nopces Royales du Treschrestien Henry de Bourbon, Roy de France E de Navarre et de la Ser.me Marie de Medicis, Prince de Toscane by Guarini. Roussin also published Desportes' work in Lyon in 1593. For Saint-Jorry, see Jean-Pierre Niceron, Mémoires pour servir à l'histoire des hommes illustres dans la république des lettres XXV (Paris: Briasson, 1734), 315; Francesco Flamini, Studi di storia letteraria italiana e straniera (Livorno: Giusti, 1895), 348; and Roméo Arbour, Répertoire chronologique des éditions de texts littéraires: l'ère baroque en France (Genève: Droz, 1977), 502.
} 
characteristics of Desportes' imitative practices, his individual poetic skills and specific contributions to early-modern French poetry, and mostly what distinguishes his poetry from his model texts. ${ }^{7}$ I will argue that this volume, possibly compiled with the intention to denounce Desportes' many Italianisms, in fact, turned out to herald his work because it reunited, in a unique bilingual collection, poetry that was well known in both Italy and France. After all, this is precisely what many Italian anthologies had done for several early modern poets. ${ }^{8}$

Philippe Desportes was an avid reader of the Italian anthologies of the Quattrocento and Cinquecento, and of the work of many Italian writers, such as Ludovico Ariosto, as his Imitations de quelques chans de l'Arioste (1572) attest. ${ }^{9}$ These translations and imitations helped the poet to perfect his lyrical skills and linguistic erudition. They also further enhanced his apprenticeship of the culture of Italian literature and of its major and minor authors. Indeed, one of Desportes' principal contributions to French literature is his pivotal role as an intermediary between, and synthesizer of, French and Italian poetry. Later on in his career, because of his contribution to the transmission of Italian poetry through French translations, he became essential reading for the next generation of French poets who took inspiration from his writings. ${ }^{10}$ His many deviations from his Italian models enabled him to produce work that embodies a poetic, linguistic, and cultural repository in which the writings of past, present, and future French poets converge in a dynamic continuum. ${ }^{11}$

The original content and format of the Rencontre illustrates Desportes' personal process of selection, imitation, and deviation from his sources, as they reveal which models incited his imagination the most. The volume is also

\footnotetext{
${ }^{7}$ Recent scholarship on Le Rencontre includes the work of JoAnn DellaNeva, 'Reading Desportes through the Italians: Two Early Modern Readers Responses', Italique XI (Droz: Genève, 2008), 31-52; Philippe Desan, 'Desportes devant la postérité: des premiers Tombeaux aux anthologies modernes', in Philippe Desportes (15461606), 495-510; Jean Balsamo, Les Rencontres des muses (Genève: Slatkine, 1992), 238. Le Rencontre is also mentioned in Roméo Arbour, Répertoire chronologique des éditions de texts littéraires, 502; in Frédéric Lachèvre, Bibliographie des recueils de poésies publiées de 1597 à 1700 (Paris: Henri Leclerc, 1901), 162; and, in more detail, in Jean-Pierre Niceron, Mémoires: 309-10.

${ }^{8}$ For a study of Italian anthologies, see Joseph Vianey, Le Pétrarquisme en France au XVIe siècle (Montpellier: Coulet et Fils, 1909), and Louise George Clubb and William G. Clubb 'Building a Lyric Canon: Gabriel Giolito and the Rival Anthologists, 1545-1590', Italica, 68 (1991), 332-44.

9 This volume also contains imitations by Saint-Gelais, Baif, and Louis D’Orléans. As Rosanna Gorris remarks, Desportes read Ariosto in order to take inspiration as a 'roman-réservoir d'histoires amoureuses et de complaintes' carefully adopting only the images that suited his taste. 'Je veux chanter l'amour la tempeste e l'orage': Desportes et les Imitations de l'Arioste, in Philippe Desportes (1546-1606), 209.

${ }^{10}$ Most scholars referenced in this study remark on Desportes' legacy to future French poets, see François Rouget, 'Philippe Desportes médiateur du pétrarquisme français', in Jean Balsamo (ed.), Les Poètes français de la Renaissance et Pétrarque (Genève: Droz, 2004), 341; Cecilia Rizza, 'Persistance et transformation de l'influence italienne dans la poésie lyrique française de la première moitié du XVIIe siècle’, XVIIe Siècle 66-7 (1965), $22-42$. See also Robert Burgess, who notes that: 'Culturally, Philippe Desportes was the most celebrated French poet of the tortured, tragic, final quarter of the sixteenth century. As a writer and as a man he is representative of his age in that he reflects every aspect of it.' 'Mannerism in Philippe Desportes', L'Esprit Créateur VI, 4 (1966), 272.

${ }^{11}$ See Gisèle Mathieu Castellani, who explains that a Renaissance poetic text becomes a repository in which several traditions converge and flourish, and mimesis becomes the proof of perfectly assimilated conventions and taste, Mythes de l'éros baroque (Paris: Presses Universitaires de France, 1981), 15-16.
} 
a product of its time and culture, and its reception is extremely indicative of Desportes' fortune and fame. Although Le Rencontre has not received much scrutiny yet, several critics have referred to it and the tongue-in-cheek tone of its preface, but mostly as a denunciation of the various misconceptions that this volume created throughout the centuries. ${ }^{12}$

The poems by Desportes included in this text originate from his Premières Cuvres and Sonnets Spirituels, whereas the Italian authors' poems are representative of the many sixteenth-century Italian anthologies that were circulating in France at the time, thereby promoting the fame and fortune of the Italian poets. They are listed on Page 5 of the Rencontre as follows:

Les Italiens [sonnets] de Angelo di Costanzo. Antonio Tibaldeo. Bernardo Tasso. Bernardino Tomitano. Dominico Veniero. Francesco Maria Molza. Giovan Mozzarello. Giacomo Sanazaro. Gio. Bat Amaltheo. Gio. Andrea Gesualdo. Gio. Iacomo Dal Pero. Girolamo Parabosco. Luigi Tansillo. L'Amanio. Remigio Fiorentino. ${ }^{13}$

More precisely, with the exception of Antonio Tebaldeo, whose poems came from his Opera d'amore di Messer Antonio Tebaldeo (Venezia, Bindoni, 1550), all of the other Italian poems are taken from the four following anthologies: I fiori de' poeti illustri, nuovamente raccolti et ordinati da Girolamo Ruscelli (Venezia: G. B. e Melchior Sessa, 1558); Rime di diversi nobili huomini et eccellenti poeti nella lingua thoscana, Libro Secondo (Venezia: Giolito, 1547); Rime di diversi eccellentiss. Auttori nuovamente raccolte libro primo con nuova additione ristampato (Venezia: Giolito, 1549); and Delle rime di diversi nobili huomini et eccellenti poeti nella lingua thoscana. Nuovamente ristampate, libro secondo (Venezia: Giolito, 1948). ${ }^{14}$ The variety of authors and texts reveals Desportes' diverse range of inspiration in addition to the breadth of his reading and writing experiences.

The Rencontre embodies an original and unique idea in early modern literature, because it can be considered a resourceful and concise bilingual anthol-

\footnotetext{
${ }^{12}$ Michiels, for example, reports the following anecdote: 'Vers la fin de sa carrière, on lui joua le mauvais tour de publier quarante-trois de ses sonnets, en regard desquels on avait imprimé les sonnets italiens qu'il avait mis à contribution, sans avertir le lecteur. Le poète ne s'émut aucunement de cette révélation.' Lxix. Philippe Desan, on the other hand, sees in this pamphlet the very beginning of serious criticism against Desportes' Italianisms: 'Ces mignardises italiennes lui seront reprochées durant tous les siècles.' 'Desportes devant la postérité: des premiers Tombeaux aux anthologies modernes', in Philippe Desportes (1546-1606), 507. See also Jacques Lavaud, in Le Pétrarquisme en France au XVI siècle (Montpellier: Coulet et Fils, 1909), 225; Flamini; Vianey, 'Une rencontre des muses de France et d'Italie demeurée inédite', Revue d'Histoire littéraire de la France, XIII (1906), 92-100, 92; Balsamo, and Gorris.

${ }^{13}$ For an extensive study of the fortune of the Italian anthologies in France, see Balsamo, 'Les Poètes français et les anthologies lyriques italiennes', Italique V (Genève: Droz, 2002), 11-32; DellaNeva, 'Variation in a Minor Key: Du Bellay's Imitations of the Giolito Anthology Poets', French Forum 14, 2 (1989), 133-46; and MarieFrançoise Piéjus, 'Lecture et écriture selon des anthologies poétiques au XVIe siècle en Italie', in Charles Adelin Fiorardo et J.-C. Margolin (eds.), L'Ecrivain face à son public en France et en Italie à la Renaissance (Paris: Librairie Philosophique J. Vrin, 1989), 337-58.

${ }^{14}$ See Flamini, Studi di storia letteraria italiana e straniera, 433-9, and DellaNeva, 'Reading Desportes through the Italians', 51.
} 
ogy in which tradition and originality mix, thereby reflecting Desportes' poems themselves. In fact, the Rencontre possesses some distinct characteristics of the same widespread sixteenth-century Italian anthologies that were the source of his inspiration. The anthologies immediately became an editorial phenomenon between 1540 and 1560, and remained a successful literary genre throughout the sixteenth century. ${ }^{15}$

These many collections can be seen as an irreplaceable and dynamic text that documents the cultural and intellectual climate of the period. They also represent the single most important book genre through which to connect the Italian poets of the Quattrocento and Cinquecento to the French poets of the sixteenth century, from the School of Lyon to the Pléiade, to neo-Petrarchism and Baroque. ${ }^{16}$ Moreover, because of their widespread circulation in France, they allowed readers in literary circles to become very familiar with the Italian poems. Poets such as Desportes often relied on their patrons' and readers'ability to recognize the source-poems, which in turn established an additional connection and continuity between writer and reader. ${ }^{17}$

Due to the fact that the forty-three poems in the Rencontre and their paired sonnets were collected and placed side by side, the volume also served as a source book that poets in search of new inspiration could consult and exploit as a tool to enhance their own imitation. Thus, as such, the Rencontre is a compelling and precious example of Desportes' role as both a reader and writer of the Italian lyric tradition. ${ }^{18}$ As Terence Cave notes, in imitation 'the activities of reading and writing become virtually identified'. ${ }^{19}$ Thus, as the close textual examination of two of his sonnets will reveal, the book reproduces Desportes' imitative process and demonstrates the crucial role of the Italian anthologies as a source of innumerable poetic possibilities. This process binds his poetry tightly to the poetry of the Italian neo-Petrarchan poets and is an indication of both his literary taste and methodical assimilation of the lyric tradition. ${ }^{20}$ By extension, the Rencontre itself becomes a poetic sourcebook and a keepsake for its dedicatee Marie de Medici, and for Desportes' successors, and it conforms to the purposes and merits of an anthology, which were to bring together poets who represented a wellestablished literary hegemony and whose work was well worth reading, circulating, and most importantly, imitating.

${ }^{15}$ See Clubb and Clubb, 'Building a Lyric Canon', 332-44.

${ }^{16}$ See Vianey, Le Pétrarquisme en France, 378-85.

${ }^{17}$ See DellaNeva, 'Variation in a Minor Key', 144.

${ }^{18}$ See DellaNeva, 'Reading Desportes through the Italians.' 43. By tracing the narrative trend and sequence of the Rencontre's poems, suggestive of Petrarch's Rime Sparse, DellaNeva also argues that the Rencontre can be considered a bilingual canzoniere.

19 Terence Cave, The Cornucopian Text Problems of Writing in the French Renaissance (Oxford: Clarendon Press, 1979), 37.

${ }^{20}$ On imitation and cultural assimilation, see Gisèle Mathieu-Castellani, Mythes de l'éros baroque (Paris: PUF, 1981), 15-16. 
Let us now examine in detail the volume and its two-page dedicatory preface, which holds the key to some of its editor's intentions. As mentioned, the volume was offered by Saint-Jorry to Marie de Medici as a presentation copy. He was undoubtedly a passionate connoisseur of French and Italian poetry, because he was able to assemble what he deemed to be the forty-three exact sources of Desportes' sonnets, as well as put together a bilingual collection of poetry for the queen of France. In simple and unpretentious language the editor explains how this volume came to be: 'Le fortune rencontre que i'ay descouvert entre les plus fameux Poëtes Italiens, $\&$ un Cigne François, sur le subject qu'Amour luy-mesme leur avoit dicté' (3). From the outset, the choice of the title 'Le Rencontre' indicates a voluntary action, a meeting of the poetry from two countries, two languages and two cultures, and a mutual and reciprocal union, which will undoubtedly be fruitful. This meeting is also a metaphor for the union of Henri IV and Marie, who are portrayed together in an elaborate image on the second page of the Rencontre. ${ }^{21}$

Furthermore, the volume is offered as a practical guide to imitation, because it is crafted as a carefully selected compilation of famous Italian poems on the right side, with the best imitation, version or interpretation in French on the facing side. Since the latter are placed on the left page, directly before their Italian counterparts, their position suggests a rather privileged space in the volume. This unique bilingual setting readily provides poets with a wide range of imitative possibilities and concrete examples. In fact, the editor explains that, because these poems describe the same things and the same concepts they are the product of admirable poetical and linguistic labour, but mostly, of similar talents and muses from both sides of the Alps: 'Madame, ceux qui s'entendent en la difference \& condition des esprits, s'esmerveillent que plusieurs à l'insceu l'un de l'autre ayent descript mesmes choses en mesmes conceptions, \& le plus souvent avec semblables paroles, \& n'en trouvent autre occasion, sinon qu'ils estoyent conduits de mesme Genie, $\&$ mesme enthousiasme' (2). The repetition of the words 'mesme' and 'semblables' expresses Saint-Jorry's viewpoint on the equality and on the many similarities of the poems. According to Cave, though, sameness may also be preserved by emphasizing the necessity of difference, which I hope the close reading of the poems will exemplify. ${ }^{22}$ Furthermore, as Thomas Greene notes 'each imitative literary work contains by definition what might be called a revivalist initiative, a gesture that signals the intent of reanimating an earlier text or texts on the far side of a rupture. ${ }^{23}$ The French poems, therefore, are Desportes' best version of imitation and of revivalist efforts that the editor could find, otherwise he would have not bothered collecting and offering

\footnotetext{
${ }^{21}$ The text is located in the Bibliothèque Nationale de France in Paris (Rés. Ye 585) as well as at gallica.bnf.fr

${ }^{22}$ Cave, The Cornucopian Text, 37.

${ }^{23}$ Thomas Greene, The Light in Troy: Imitation and Discovery in Renaissance Poetry (New Haven: Yale University Press, 1982), 37.
} 
them as a keepsake to the queen of his country. Thus, this precious donation, compiled and packaged for the monarch, Italian-born now living in a foreign land, crucially emphasizes similarities in themes and tastes between the two poetics, thereby underscoring Renaissance conventions of imitation. By claiming that the French and Italian poets reach the same perfection (4), SaintJorry becomes the custodian of this intertextual dialogue. Moreover, he not only stresses the quality and harmony accomplished in this dialogue, but also justifies the literary merit achieved by all sixteen celebrated authors.

The editor is also attempting to champion his Rencontre by highlighting its linguistic value. Since the queen is well versed in poetry and speaks French fluently, ${ }^{24}$ he asks her to judge the quality and grace of the poems: 'Le iugement en est à bon droit deferé à vostre Majesté, qui possede parfaictement la cognoissance de l'une [langue], \& s'acquiert tous les iours les graces parfaictes de l'autre' (4). Moreover, with the presentation copy of a bilingual anthology, Saint-Jorry also intended to make Marie de Medici feel at home by showing, perhaps, how much the French poet was indebted to the poets of her native country, and thus, how his work was not really all that foreign after all. By collecting and offering the eighty-six sonnets, Saint-Jorry brought together two national poetics. After all, the monarch herself embodies the same meeting of two cultures or muses, as the title suggests, and the union of two countries that share very similar literary interests, traditions, cultures, and languages. The volume is also a product of the culture of collecting in vogue during the sixteenth and the seventeenth centuries, meant as a treasured keepsake to be added to the queen's collections, with its content of the best Franco-Italian poetry had to offer.

The Rencontre is a concrete bilingual and intercultural compendium, a personal canzoniere offered to the queen as a 'trésor poétique', and as a cultural 'outil d'acclimatisation'. This is not inconsistent with the idea that the editor intended to reveal Desportes' sources, but this revelation does not seem to be the primary motivation for assembling the collection. ${ }^{25}$

In fact, although the tone of the beginning of the dedication appears to insinuate that the editor gathered these sonnets in order to expose Desportes to ridicule by revealing forty-three unequivocal sources of his work, ${ }^{26}$ the repetition of the adjectives 'same' and 'similar' ('mesmes' and 'semblables'),

\footnotetext{
${ }^{24}$ See Philippe Delorme, who notes: 'Son français devient vite correct au point qu'elle finira par affirmer, dans une lettre du 24.10.1618: "Io non so più scrivere l'italiano." ' Histoire des reines de France. Marie de Médicis (Paris: Pygmalion, 1998), 84.

${ }^{25}$ Balsamo remarks that: 'L'ouvrage cependant, si on veut bien le lire, ne présente pas une dénonciation ironique de 'plagiats' de Desportes. Dédié à la reine Marie de Médicis, vivant symbole de la rencontre des Etats qui présidait à la rencontre des Muses, il évoquait l'heureuse émulation entre les deux langues sœurs. S'il rappelait les similitudes, il insistait sur les écarts entre des poèmes semblables et d'une même excellence.' Les Rencontres des muses, 237-8.

${ }^{26}$ This part reads: 'Ceux qui s'entendent en la difference \& condition des esprits, s'esmerveillent que plusieurs à l'insceu l'un de l'autre ayent descript mesmes choses en mesmes conceptions, \& le plus souvent avec semblables paroles, \& n'en trouvent autre occasion, sinon qu'ils estoyent conduits de mesme Genie, \& poussez d'un mesme enthousiasme,' 3 .
} 
instead calls attention to the editor's main intention, which was to bring together analogous concepts in poetry. Of course, he also indirectly praises his own contribution to the literatures of France and Italy in assembling a precious sourcebook of eminent poetry.

Furthermore, despite the differences in style and language, Saint-Jorry claims that the authors in the Rencontre: 'conviennent tous neanmoins à ceste perfection' (4), thereby praising in equal measure the linguistic and lyric perfection achieved by both Desportes and the Italian poets. His main criterion for selection is that the source poems should bear similarities to Desportes' texts. In some cases, these sources constitute the exact models, because the French poet followed Renaissance practices of imitation and abided by the Petrarchist tradition whose characteristics enabled the monarch and other readers to better appreciate and value the small collection.

A key statement in the preface: 'sur le suiect qu'Amour luy-mesme leur avoit dicté'(3) identifies love as the main topic that gives inspiration to both groups of poets and binds them together. The poems not only share the same Petrarchan code and language, they also follow the Canzoniere's trajectory, in that the last six poems' content is entirely spiritual. For Desportes, as reader and writer, the Rencontre is an affirmation of his lyrical skills in choosing his models and adapting them to the French language and style, and a testimony to his ability to create poems that subsequently acquire a life of their own, with a distinct tone and sensibility that, in turn, inspired his contemporaries and successors.

The following analysis of the paired poems will show exactly how Desportes deviated from his Italian sources, thereby distinguishing himself and his style from them. Although he was initially inspired by the images of the Italian sonnets, the choice and control of vocabulary, his lyric attitude and themes, undeniably produced poetry that is both distinctive and inventive.

The first sonnet is paired with a poem by Luigi Tansillo (1510-68), a well-known Italian poet from Naples, who was widely represented in the Italian anthologies. Just like Desportes, Tansillo was an experienced and admired court poet whose writings were one of the main attractions at the balls and social events of Vicerè Pietro Toledo and his son Garzia. ${ }^{27}$ Petrarch's intertext is always apparent in Tansillo's lyrics, thereby producing a remarkable continuity between the multi-layered Italian tradition, from Petrarch to Tansillo, and French tradition, from the Pléiade to neo-Petrarchism.

\footnotetext{
${ }^{27}$ For Tansillo's life and work, see Il Canzoniere edito ed inedito, Erasmo Pèrcopo (ed.), Vol. I, (Napoli: Tipografia degli Artigianelli, 1926), and the most recent critical study by Erika Milburn, Luigi Tansillo and Lyric Poetry in Sixteenth-Century Naples (Leeds: Maney Publishing, 2003).
} 


\section{Desportes:}

Espouventable Nuict, qui tes cheveux noircis Couvres du voile obscur des tenebres humides, Et des antres sortant par tes couleurs livides, De ce grand Univers les beautez obscurcis. Las! Si tous les travaux par toy sont addoucis, Au ciel, en terre, en l'air, sous les marbres liquides, Or que dedans ton char le silence tu guides, Un de tes cours entiers enchante mes soucis. Je diray que tu es du Ciel la fille aisnee, Que d'astres flamboyans ta teste est couronnee, Que tu caches au sein les plaisirs gracieux. Des amours \& des ieux la ministre fidele, Des mortels le repos: bref tu seras si belle, Que les plus luisans iours en seront envieux.

(XXVII 58, Hippolyte71)

\section{Tansillo:}

Orrida notte, che rinchiusa il negro Crin, sotto'l vel de l'umide tenebre, Da sotterra esci, e di color funebre, Ammanti il mondo, e spoglilo d'allegro. Io, che i tuoi freddi induggi irato, \& egro, Biasmo non men, che la mia ardente febre, Quanto ti loderei, se le palpebre, Queto chiudessi un de'tuoi corsi integro. Direi, ch'esci dal cielo, e' c'hai di stelle Mille corone, onde fa'l mondo adorno, Che ne chiami al riposo, e ne rapelle, Da le fatiche, e ch'al tuo sen soggiorno, Fanno i diletti, e tante cose belle, Che se n'andria tinto d'invidia il giorno.

The close textual reading demonstrates the ways in which the French sonnet differs from its model with simple adaptations or, at times, deep-rooted transformations. Desportes' sonnet is evidently inspired by Tansillo's, but is by no means a translation. A linguistic and thematic analysis will prove very useful in determining Desportes' creative vein: the main common trait is the lyrical expression and powerful imagery of the night and its personification.

Both poets address an intimate and erotic monologue to the frightful ('Espouvantable') or horrid ('Orrida') night. Tansillo's choice of the first word sounds exceedingly harsh with its double 'rr' whereas Desportes' choice is mitigated and appeased by its nasal sound. Both images evoke the night's powers to form dreams and peace, enveloping the sleepy world with shiny stars (Desportes' 'astres flamboyans' and Tansillo's'di stelle/ Mille corone'). While borrowing this opening image, the French poet transforms the frightful night, 
'Espouvantable Nuict', into an idyllic phenomenon that extends to the entire universe. The night is likened to an irresistible woman, with her appealing hair, breasts, and beauty. The striking similitude of the night and the dark hair (Desportes' 'cheveux noircis' and Tansillo's'il negro/Crin') dominates both first quatrains, but the French one is also governed by the power of the night to obscure the beauty of the entire universe ('De ce grand Univers les beautez obscurcis'). This image does not appear to be as dominant in the Italian poem, because Tansillo brings into play the world ('Ammanti il mondo'), rather than the greatness of the universe, which in the French poem is given a capital letter ('De ce grand Univers'). The intensity of this image has already been foreshadowed by the choice of the French word 'astres', a more appropriate macrocosmic element than the Italian word, 'stelle'. Since both astri and stelle exist in Italian, as well as astres and étoiles in French, Desportes' preference for astres magnifies even further his suggestive portrait of the night. Moreover, this universal vision is also intensified in the second quatrain of the French sonnet with a typical Petrarchan enumeration of the elements: 'Au ciel, en terre, en l'air, sous les marbres liquides' so as to further empower the night in the sky, on earth, in the air, and in the seas; nothing can escape its darkness and magnitude. Both first tercets bring the poets back to their personal reflections with an immediate and upfront urgency to personalize their poems: Desportes' 'Je diray', and Tansillo's 'Direi'. If both poets were lost in the contemplation and admiration of the night, they now refocus and look inward. Here again, Desportes departs from the model by bestowing upon his night the privileged status as the sky's firstborn child: 'tu es du Ciel la fille aisnee', yet another tactic to empower and venerate night-time. Both poets evoke darkness's erotic and influential properties (Desportes: 'Que tu caches au sein les plaisirs gracieux/ Des amours et des ieux la ministre fidele,' and Tansillo: 'e ch'al tuo sen soggiorno,/ Fanno i diletti, e tante cose belle'). In this lyrical representation of the night and its obscure dimensions, the two paired sonnets conclude with earnest praise, whereby the poets express, in similar terms, their fascination with this magic night of dreams: Desportes: 'bref tu seras si belle,/ Que les plus luisans jours en seront envieux'; Tansillo: 'Che se n'andria tinto d'invidia il giorno.' The days are envious of the beauty of the night. However, by adding a superlative adjective, 'les plus luisans' the French narrator stresses once more the power of darkness over light, thereby crafting his final verse more persuasively.

The second sonnet is an additional example of the underlying tensions in the process of imitation and creation. It is undoubtedly inspired by the Italian model. However, Desportes' poem departs from it almost immediately. It is paired with a sonnet by Angelo di Costanzo (1507-91). ${ }^{28}$ A poet and magistrate from a noble family in Naples, Costanzo was principally known as one of

\footnotetext{
28 Angelo di Costanzo, Rime (Bologna: Barbiroli, 1709). See also Vianey, 'Desportes et Angelo di Costanzo', Révue d'Histoire littéraire de la France, XV (1908), 330-41.
} 
the most original imitated Petrarchists in both Italy and France through his inclusion in the sixteenth-century Italian anthologies. ${ }^{29}$

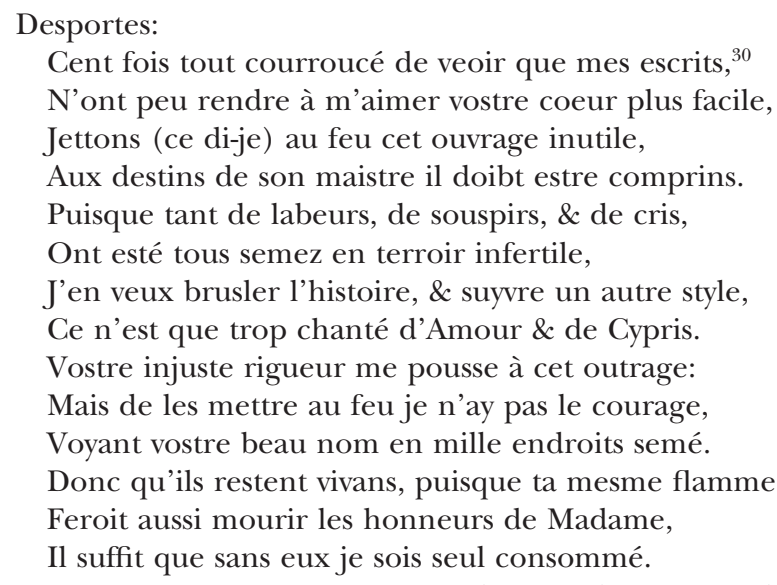

\section{Costanzo:}

S'alcuna volta avien, ch'io d'arder tente

Le rime mie; che senza haver giovato

A porre in voi pietà, v'hanno acquistato

Più che fama futura, odio presente.

De la giust'ira sua tosto si pente

Il cor, vedendo il bel nome segnato,

In lor sì spesso, e pargli (ahi duro fato!)

Por le viscere sue nel foco ardente.

E grida: Restin pur' eterne, e viva

Con lor Madonna, e non sia'n questa etate,

Ch'il mio morire à crudeltà le ascriva.

Ch'io non vuò c'habbia mai di me pietate,

Con scemar di sua gloria anima viva,

Nè macchi il sangue mio la sua beltate.

$(\mathrm{XXX}, 65)$

The paired sonnets start with a similar image. In both, the narrator struggles with the desire to burn the pages in which he writes about and celebrates his beloved, because they fail to make her fall in love with him. Constanzo writes wittily that, rather than resulting in his future fame, his verses produced hate. Desportes, on the other hand, simplifies the stanza, and in a single verse, he

29 See Vianey, Le Pétrarquisme en France, 194, and Marius Piéri, Pétrarque et Ronsard ou de l'influence de Pétrarque sur la Pléiade française (New York: Burt Franklin, 1968), 25.

${ }^{30}$ I correct from 'esprits,' as modern editors of Desportes' work have done. See Graham, Cléonice, dernières amours, 91. 
clearly and forthrightly states that his art of writing poetry did not gain him his lady's love: 'N'ont peu rendre à m'aimer vostre cœur plus facile'. Both poets are conscious of the power of their writings: Desportes extends the image into the following quatrain, where, again with a Petrarchan enumeration ('Puisque tant de labeurs, de souspirs, \& de cris'), he stresses his work's infertility and completely forgoes the second image developed by Costanzo ('Il cor, vedendo il bel nome segnato'). However, the French poet creatively weaves together the destiny of his useless writings ('ouvrage inutile') with his own destiny: 'Aux destins de son maistre il doibt estre comprins.' While powerfully closing the first quatrain, this original verse seals the poet-persona's fate with the fate of his creation, and both seem condemned to end.

Desportes' sonnet appears less elaborate because he does not make use of Costanzo's concettos, such as: 'v'hanno acquistato/ Più che fama futura, odio presente.' This is the major difference between the two sonnets: Desportes prefers a more lyric and traditional approach to facing unrequited love, without drawing on strong and sometimes fierce words and images. Rather, he maintains an attitude of relative tolerance, expressed simply in the following verse: 'So that they may continue to live' ('Donc qu'ils restent vivans').

Costanzo persists with the personification of his screaming heart in the first tercet: 'E grida', thereby extending a second concetto, and actually articulating it even more vividly with the verse: 'Ch'il mio morire à crudeltà le ascriva.' Desportes, on the other hand, does not become this dramatic; rather, he continues with an acquiescent attitude toward his gloomy destiny: 'Vostre injuste rigueur me pousse à cet outrage' and again, in the last tercet: 'Donc qu'ils restent vivans'. This milder mind-set is also reflected in the language, which, as we have seen, never becomes violent or grotesque, as in Costanzo's poem: 'Por le viscere sue nel foco ardente' and 'Nè macchi il sangue mio la sua beltate', where, literally, the lover-persona's blood would stain his beloved's beauty.

Desportes concludes with a completely different image, bestowing upon his reader a more serene stance toward unrequited love: 'Il suffit que sans eux je sois seul consommé.' The pride of the Italian narrator in the last tercet: 'Ch'io non vuò c'habbia mai di me pietate' is completely absent in the French sonnet, demonstrating that, if at the beginning, Desportes took inspiration from the Italian model, he crafts his own narrative and departs significantly from it, in imagery, language, and lyric tone throughout the poem, until the very end. In fact, Desportes tones down Costanzo's violent images and language, and this is characteristic of his style, which has been labelled 'doux coulant', fluid, and elegant, and which privileges a more measured, elegant, and gracious approach to lyric themes. ${ }^{31}$

\footnotetext{
${ }^{31}$ See, for example, Graham, who claims that Desportes' main characteristics are: 'la fluidité, l'élégance, la grâce légère,' and claims that: 'ses contemporains admiraient ses vers 'doux coulants.' In 'Le Rôle de Desportes dans la poésie française', Revue de l'Université d'Ottawa (1965), 54.
} 
In conclusion, by intentionally placing the poems side by side, Saint-Jorry undoubtedly brings out the few similarities and the significant deviations between the two texts. In the first poem, where the initial imagery remains the same, Desportes adds intensity and grandeur by his careful choice of vocabulary. In the second, he transforms the rebellion of the Italian model into acceptance; the entire sonnet is tempered by simpler and less violent language. Both French sonnets follow French versification, they are independent and original, thus demonstrating the author's own creativity in deviating from their Italian sources. The analysis of the dedication and of the four sonnets enables us to reflect on Desportes' imitative style and his vibrant approach to intertextuality, and suggests several important conclusions about the mimesis and creative process intrinsic to his work.

First, both examples show that, while the French poet at first took inspiration from his Italian sources, he almost immediately departed from them, and produced instead separate and distinct texts, with unique and imaginative characteristics, and with a language that is inventive, resourceful, and representative of his own style. If at first the images and themes of the source deeply inspired Desportes, a distinct and quite different progression unfolds into an independent new poem in which changes, additions, omissions, and most importantly, deviations unfold in order to create an individual work.

Second, linguistically, the skilled French poet does not use Italianisms, but rather, a vocabulary springs from his own native vernacular, which he had the opportunity to develop and refine through his many translations and adaptations. As Balsamo notes, Desportes' role in the development of the French language is of primary importance, precisely as a result of these painstaking exercises. ${ }^{32}$ As an avid reader of Petrarch and of the Petrarchist poets, an assiduous member of the salons and of the Palace Academy, and of the Italianate court of Henri III, and also as a result of his sojourns in Italy, Desportes did not perceive Italian as an entirely foreign language. ${ }^{33}$ With his disciplined linguistic exercises and fruitful imitations, the French poet sought to make the Italian authors of the Quattrocento and Cinquecento more contemporaneous and less foreign, bringing their language and style closer to new French linguistic structures and possibilities. ${ }^{34}$

Third, with his work, Desportes enriched the French language itself. His linguistic and stylistic preferences persisted with the next generation of

\footnotetext{
32 'Traduire de l'italien. Ambitions sociales et contraintes éditoriales à la fin du XVIe siècle', in Dominique de Courcelles (ed.), Traduire et Adapter à la Renaissance (Paris: Ecoles des Chartes, 1998), 89-98.

${ }^{33}$ His private library was considerably furnished with various genres of Italian books, as Isabelle de Conihout notes in 'Du nouveau sur la bibliothèque de Desportes et sur sa dispersion', in Philippe Desportes (1546-1606), 121-60.

${ }^{34}$ For more detail about Desportes' readings of sixteenth-century Italian anthologies, see Vianey, Le Pétrarquisme en France, 232-44; Lavaud, 274-81; and Rouget's more recent article, 'Philippe Desportes et la logique des recueils poétiques', in Réforme, Humanisme et Renaissance, 62 (June 2006), 99-110.
} 
French poets, thereby establishing a new phase of imitatio. ${ }^{35}$ In his preface, Saint-Jorry addressed precisely the issue of linguistic competence and aptitude of the French and Italian poets, thereby stressing the effort that all of them undertook in order to represent best their own vernacular: 'car chacun d'eux taschant à son possible de representer l'excellence de la pureté de sa langue, $\&$ de la merveilleuse fecondité de son style' (3-4). In borrowing only the elements that better corresponded to his personal tastes and poetic vein, Desportes weaved his sources into his writings through a conscientious process of self-inscription within the lyric traditions of France and Italy, of Petrarchism and neo-Petrarchism, while skilfully crafting his personal poetic identity.

Finally, Desportes and the purported editor seem to have shared similar goals in their endeavours: to bring together two parallel literatures and cultures, to respond to their readers' tastes and expectations, and to fit with the literary conventions and tradition of their time. If Le Rencontre des muses de France et d'Italie was at first a gift to Marie de Medici, carefully crafted as a bilingual anthology and a personal canzoniere, it also came to mark an important moment in the literatures of France and Italy of the early modern period. Moreover, it remains a compelling text today. This little volume, after all, turned out to be yet another avenue through which Desportes' work was circulated and became known, thus turning out to be a publication which furthered his career and reputation, and which connected his poetry more meaningfully to the poetry of well-known Italian authors.

The University of Michigan-Dearborn

\footnotetext{
${ }^{35}$ Several scholars have remarked on Desportes' significant role in establishing a clearly distinct phase in French poetry, thus serving future generations of French poets. See, for example, Rouget, who notes that Desportes distances himself from the previous generation of poets while guiding his contemporaries toward a new phase, 'Philippe Desportes et les inflexions métriques de la voix lyrique', in Philippe Desportes (1546-1606), 297, and Balsamo, who points out that Desportes' language had a significant impact on sixteenth- and seventeenth-century French, Les Rencontres des Muses, 45.
} 